\title{
Translations of Two Poems by Ouled Ahmed
}

Houssem Ben Lazreg, University of Alberta, Edmonton

$$
\text { جو اب الشرط أولاد أحمد }
$$

$$
\begin{aligned}
& \text { إذا كنتَ شعبًا عظيمًا... }
\end{aligned}
$$

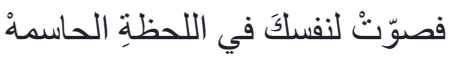

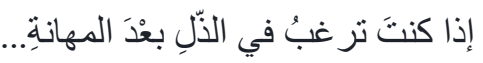

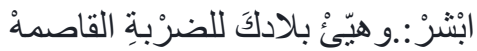

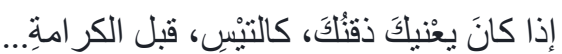

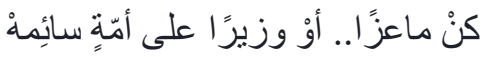

$$
\begin{aligned}
& \text { إذا كنتَ تبحسثُ عنْ خدْمَة... } \\
& \text { لا تكنْ خادمًا للحكو ماتِ..قلْ:إنّها الخادمهُ } \\
& \text { إذا لمْ تجذْ حجر ا للوضويء... } \\
& \text { فقلْ:أكثرُ الدينِ في سورة المائده: } \\
& \text { اذا كان ربي حبيبيَّكَ وحدكَّ... }
\end{aligned}
$$

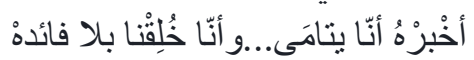

$$
\begin{aligned}
& \text { إذا كنت تصنمدُ في الاعتصام الأخير.... }
\end{aligned}
$$

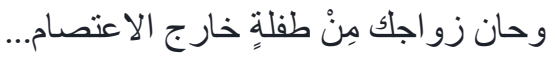

$$
\begin{aligned}
& \text { فلا تتزوجْ سوى صامده: }
\end{aligned}
$$

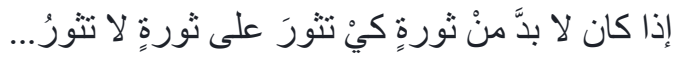

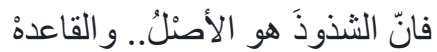

$$
\begin{aligned}
& \text { إذا لمْ تطالْْ كتنابًا عدَا و احدًا.. }
\end{aligned}
$$

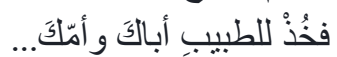

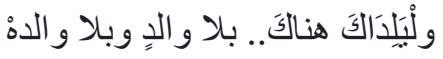

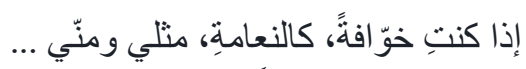

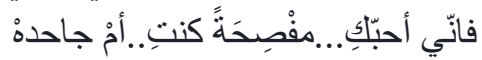

$$
\begin{aligned}
& \text { إذا كنتِ خارطةً كالتي نحنُ فيها. } \\
& \text { وأنثى... } \\
& \text { تُطِلُّ على البحرِ و الملكوتِ }
\end{aligned}
$$

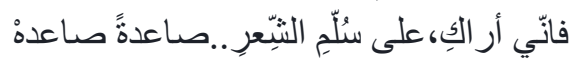

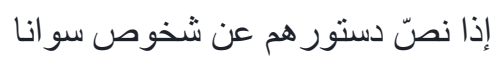

$$
\begin{aligned}
& \text { وعن مَزْ أة لا نر اها }
\end{aligned}
$$




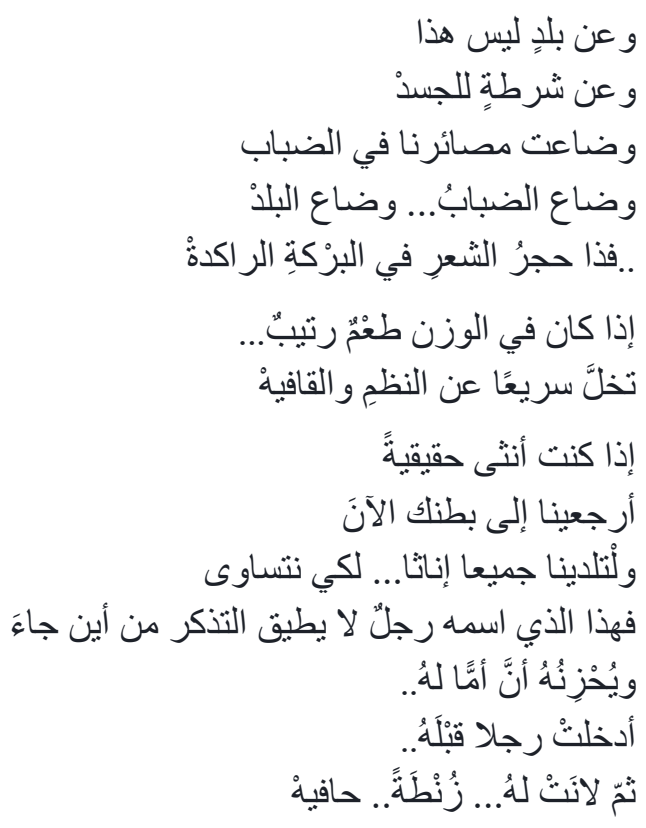

\section{Conditional response}

If you are a great nation

then vote for yourself at the crucial moment

If you want humiliation after disgrace

rejoice: and prepare your country to the deadly blow

If you care more about your goatee than your dignity

Be a goat... or a minister for a wretched nation

If you are looking to serve

Do not be a servant for rulers... but say: they are the servants

If you do not find a stone to perform ablution ${ }^{1}$

then say: most of the Islamic teachings are in chapter Al-Maidah ${ }^{2}$

If you are the only one to love God

then tell him that we are orphans... and that we were created in vain

If you resist in the last sit-in ${ }^{3}$

\footnotetext{
1 "Wudu" is the Islamic procedure for washing parts of the body (hands, mouth, face, arms, head, feet) using water before performing the prayers.

2 "Surat al-Ma'ida". Literally, it means the table. It is the fifth chapter of the Quran and addresses topics such as animals which are forbidden to eat, the ablution steps, Isa (Jesus') and Musa's (Moses) missions.
} 
and it is time to marry a woman from outside the sit-in then marry only a resistant one

If there is a need to revolt against a revolution that does not revolutionize things then exception is the principle... and the norm

If you have read only one book then take your parents to a doctor and let them give birth to you there... like an orphan

If you are afraid as an ostrich, like me and of me then I love you... whether you are frank or evasive

If you are like our current map, like a female that overlooks the seas and the kingdoms of heavens then I see you.. on the ladder of poetry... rising further away

If their constitution refers to people other than us to an invisible woman to a country other than this one to a police of desire and if our destinies are lost in the fog and if the country, like the fog, got lost too then throw the stone of poetry in the stagnant pond

If the beat becomes monotonous get rid quickly of rhythms and rhymes

If you are a real woman take us all back to your womb now and give birth to all of us females... so that we become equals for this so-called man cannot bear to remember whence he came from and it saddens him that his mother previously loved a man then gave herself up to him, unclad and barefoot

If you are a great nation then vote for yourself at the crucial moment

\footnotetext{
3 There is a reference here to a sit-in organized in Kasbah, Tunis against the "Troika"(coalition) government led by the Islamists.
} 
TranscUlturAl, vol. 9.1 (2017), 171-179.

http://ejournals.library.ualberta.ca/index.php/TC

If you want humiliation after disgrace

rejoice: and prepare your country to the deadly blow. 


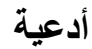

$$
\begin{aligned}
& \text { أعنّي عليه } \\
& \text { لقد عقرو اناقتي } \\
& \text { و أباحو ا دمي في بيوت أذنت بأن لا ير اق دم فوق سجادها! } \\
& \text { أعوذ بك الآن من شر أهلي } \\
& \text { يبيعون خمر ا رديئا } \\
& \text { ويؤذون ليل السكارى البريء! } \\
& \text { ** * } \\
& \text { إلهي } \\
& \text { لقد تم بيع التذاكر للآخرة } \\
& \text { ولم أجد المال، و الوقت، و العذر لثرة } \\
& \text { كي أقتني تذكره } \\
& \text { فمزّق تذاكر هم يا إلهي } \\
& \text { ليسعد قلبي.. ألم تعد الناس بالمغفرة } \\
& \text { إلهي } \\
& \text { أريد جر ادا لكل الحقول } \\
& \text { ومحو جميع النقاط } \\
& \text { وقحطا لكل الفصول } \\
& \text { وطير ا أبابيل للاحتياط لون النول } \\
& \text { *** } \\
& \text { صدقت إلهي }
\end{aligned}
$$

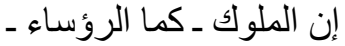

$$
\begin{aligned}
& \text { إذا دخلو ا قرية أفسدو ها الروناء }
\end{aligned}
$$

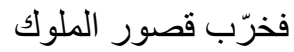

$$
\begin{aligned}
& \text { ليصلح أمر القرى فرون } \\
& \text { لينبت دود مكان البلح } \\
& \text { ذهبنا جميعا إلى الانتخاب } \\
& \text { ولم ينتخب أحد من نجح الانغاب } \\
& \text { إلهي } \\
& \text { حبيبي } \\
& \text { ويا سندي } \\
& \text { نشرت كتابا جديدا }
\end{aligned}
$$




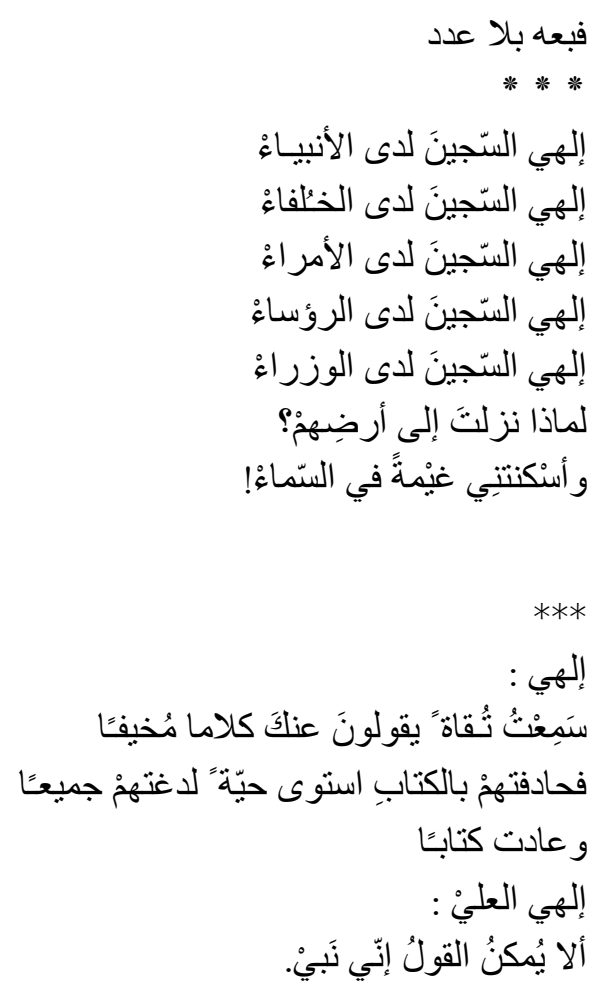

\section{Supplications}

\section{O God}

Help me resist them

They slaughtered my camel and authorized the shedding of my blood

in places where you forbade the spilling of blood on its prayer rugs.

O God

I seek refuge in you from the evil of my people

They sell bad wine, and spoil the drunkards' innocuous night.

\section{O God}

The tickets for the Afterlife were sold out

and I did not have the money, the time, and the reason

to buy one

so please, tear their tickets, O God

and let my heart rejoice

did you not promise us forgiveness.

\section{O God}

Send locusts to devastate all the fields 
and to erase all the points

send droughts for all seasons

and swarms of birds to destroy their supplies.

O my God, you spoke the truth

kings, like presidents

when they conquer a village

they ruin it

so $\mathrm{O}$ my God, please destroy their palaces

so that order shall be restored in villages.

\section{O God}

Let maggots grow instead of dates

We all went to cast our votes

but no one elected those who won.

O God

My love

My support

I published a new collection

So, please let it sell without limitation

O God, you were taken prisoner by the prophets

O God, you were taken prisoner by the Caliphs

O God, you were taken prisoner by the princes

O God, you were taken prisoner by the presidents

O God, you were taken prisoner by the ministers

Why did you descend to their land

and housed me in a heavenly cloud.

O God

I heard the pious people saying frightful things about you so when I threw my book at them, it turned into a snake that bit them and turned back into a book.

O God, the Most High

Am I not a prophet indeed?

\section{Translator's Note}

Ouled Ahmed was born on April 4th, 1955 in the city of Sidi Bouzid, the cradle of the Tunisian Revolution. He is among the prominent literary figures that fought against tyranny and oppression by the power of the word. His early poetry was openly rebellious and expressed outrage at the political, religious and social shackles facing young people who aspire to freedom 
and dignity. Ouled Ahmed's seditious activities led to his imprisonment in the mid-1980s under Habib Bourguiba's rule. During the early years of Ben Ali's presidency (1987-2011), the regime continued prosecuting and chasing the poet, causing him to eventually lose his employment. He traveled to France but he returned to Tunisia at the beginning of the nineties and founded the first House of Poetry from 1993 to 1997. Ben Ali's regime tried to win the heart of the poet by granting him the Order of Cultural Merit for founding the House of Poetry but Ouled Ahmed refused it. While he remained under constant harassment, he wrote poetry and mocked the regime, which resulted into his expulsion from his position at the Ministry of Culture.

In addition to his militantism against Habib Bourguiba and Ben Ali's regimes, Ouled Ahmed was a vocal critic of the Islamists who came to power after the 2011 Constituent Assembly Elections. Among his most important publications are: The Six-Day Anthem (1984), I Have No Problem (1998), and The Poetic Leadership of the Tunisian Revolution (2013). In 2011, Ouled Ahmed received The Carthage International Poetry Prize.

Below I explain some of the cultural and political references found in the poems. In "Conditional Response", the poet uses the term "wndu", which refers to the Islamic procedure for washing body parts (hands, mouth, face, arms, head, feet) with water before performing prayers. Moreover, he makes reference to "surat" (chapter) Al-Maidah. Literally, Al-Maidah means "the table" and constitutes the fifth chapter of the Quran; it addresses topics such as animals that are forbidden to eat, the ablution steps, Isa (Jesus') and Musa's (Moses) missions as Prophets. Politically speaking, the poet expresses his rage towards the Islamists who focus extensively in their platforms on trivial issues, such as dress code and physical appearances (having a goatee than dignity). I addition, he rebels against their perception of women, which he considers degrading.

In the second poem "supplications", Ouled Ahmed calls upon God to send his wrath on a group of his kinsmen. He denounces how the Islamists manipulate the masses, using religious discourse and the Quranic text for their own interests. In the lines "when I threw my book at them, it turned into a snake that bit them and turned back into a book", there is a reference to the story of the Prophet Moses' staff that turned into a snake after he threw it on the ground. Thus, the poet compares the confrontation that took place between Moses and the Pharaoh with his own struggle against the Islamists.

To conclude, Ouled Ahmed was one of the vocal critics against political or religious dictatorship and oppression in Tunisia. He was one of the most engaged poets as he participated in many sit-ins against the successive governments. His incessant conflict with the Islamists subjected him to death threats. As a secular literary figure, he never recognized those who appoint themselves as ministers of God on earth as having any legitimacy. 


\section{REFERENCES}

Bekri, Tahar. «Aux frères indicateurs. »L'Orient Littéraire, 6 Avril 2016, http://www.lorientlitteraire.com/article details.php?cid=11\&nid=3919. Accessed 17 May 2017.

Chaouch, Rebecca. «Décès du poète tunisien Sghaïer Ouled Ahmed. » Jeune Afrique, 6 Avril 2016, http://www.jeuneafrique.com/315912/societe/deces-poete-tunisien-sghaierouled-ahmed/. Accessed 17 May 2017.

«Tunisie: Décès du poète Sghaier Ouled Ahmed. »Webdo T.n, 6 Avril 2016, http://www.webdo.tn/2016/04/05/tunisie-deces-poete-sghaier-ouled-ahmed/. 